\title{
Svangerskap og fødsel etter fedmeoperasjon: Hva bør jordmødre vite?
}

Hvilke utfordringer opplever jordmor i møte med fedmeopererte gravide kvinner, og hvordan kan hun best ivareta kvinnen gjennom svangerskap, fødsel og barseltid?

\section{Forfatter}

\section{Mia Søpstad}

Jordmor

St. Olavs hospital

\section{Nøkkelord}

Fødsel Fedmekirurgi graviditet jordmødre

Sykepleien 2018 106(69455)(e-69455)

DOI: https://doi.org/10.4220/Sykepleiens.2018.69455

\section{HOVEDBUDSKAP}

Stadig flere kvinner med fedme benytter seg av fedmekirurgi. Dette medfører nye utfordringer for jordmødre. Det handler om kvinnens helse og livskvalitet, og om fosterets utvikling.

Velkjente komplikasjoner etter fedmekirurgi er blant annet ernæringsmangler, dehydrering og tarmhernier.

Økt overvåkning av fedmeopererte kvinner under svangerskap, fødsel og barseltid er nødvendig. 
Norge er et av de tryggeste landene i verden å føde barn i, med lave tall for alvorlig skade eller dødsfall hos mor og barn knyttet til fødsel. Samtidig er overvekt og fedme et økende folkehelseproblem, noe som også angår oss som jordmødre, i og med at mange overvektige er kvinner i fertil alder.

Fedmekirurgi har de senere årene blitt et mer og mer kjent begrep, og stadig flere kvinner med fedme benytter seg av denne typen behandling (1). Dette medfører nye utfordringer for helsevesenet, og da spesielt for gynekologer og kirurger, men også for jordmødre. Det handler ikke da bare om kvinnens helse og livskvalitet, men også om fosterets utvikling (1).

Hva betyr det når disse kvinnene blir gravide etter gjennomgått kirurgi? Hva vet egentlig jordmødrene om disse kvinnene, og hvordan kan vi best ivareta dem under svangerskap, fødsel og barselomsorg?

\section{Mangler retningslinjer}

Interessen min for temaet ble for alvor vekket under praksisstudier ved en fødeavdeling. Ifølge en av jordmødrene er overvekt og fedme en stadig vanligere utfordring i den kliniske hverdagen. I møte med en overvektig kvinne på den ordinære ultralydundersøkelsen i svangerskapsuke 18 hadde hun hatt store problemer med å få oversikt over fosterets organer, nettopp på grunn av mors fedme.

\section{三 «I møte med en overvektig kvinne hadde hun hatt store problemer med å få oversikt over fosterets organer.»}

Videre var hun frustrert over hvordan en skal møte disse kvinnene under svangerskap, fødsel og barseltid.

Det hun sier, støttes også i litteratur og aktuell forskning; «examination was limited due to body habitus» (2). 
Videre ble jeg etter flere samtaler med gynekologer og jordmødre ved en kvinneklinikk gjort oppmerksom på de kvinnene som gjennomgår fedmekirurgi, og utfordringene, men også fordelene, dette kan bringe med seg dersom kvinnen i etterkant blir gravid og føder et barn. Samtidig er det meg bekjent få eller ingen retningslinjer for hvordan en skal ivareta disse kvinnene.

\section{Fedmekirurgi}

I litteraturen som er anvendt i denne artikkelen, er bariatric surgery et gjennomgående begrep. Dette er i norsk og skandinavisk litteratur oversatt til «fedmekirurgi». Fedmekirurgi deles inn i to: restriktive prosedyrer og malabsorptive prosedyrer (3).

Inngrepene kan utføres enten laparoskopisk eller via åpen kirurgi. Det er viktig at jordmor kjenner til forskjellen på disse inngrepene, da det får betydning for hvilken oppfølging kvinnen trenger i svangerskap, fødsel og barseltid. Inngrepene vil derfor i det følgende beskrives i korte trekk.

\section{Restriktive inngrep}

Restriktive prosedyrer tar sikte på å begrense mengden mat som kan konsumeres på en gang. Laparoskopisk gastrisk banding (LAGB) er den mest brukte restriktive prosedyren, selv om den ikke er så vanlig akkurat i Norge (4). Her legges en silikonring rundt inngangen til magesekken, og denne kan reguleres i diameter.

Denne typen inngrep gjør at en raskere oppnår metthetsfølelse og dermed også begrenser inntaket av kalorier. Fordelen med dette inngrepet er at det er forholdsvis enkelt å utføre, har få komplikasjoner, og en kan individuelt tilpasse størrelse på inngangen til magesekken basert på kostråd og eventuelle bivirkninger (5).

\section{Malabsorptive inngrep}


I en malabsorptiv prosedyre blir magesekken og deler av tynntarmen koplet ut, slik at absorpsjonen av fett og kalorier blir begrenset. Dette kalles også for gastrisk bypass-operasjoner. Disse prosedyrene anses for å være mer effektive enn de restriktive prosedyrene hva gjelder å behandle komorbide tilstander som hypertensjon og diabetes (5).

I Norge har denne prosedyren i økende grad blitt erstattet med langsgående ventrikkelreseksjon, eller gastric sleeve, som gir en trang, rørformet magesekk (4).

\section{三 «I Norge har gastrisk bypass-operasjoner i økende grad blitt erstattet med langsgående ventrikkelreseksjon.»}

Den mest populære fedmeoperasjonen i USA er Rouxen-Y gastric bypass (RYGB). Dette inngrepet er en kombinasjon av restriktive og malabsorptive kirurgiske teknikker. Her lages magesekken mindre, samtidig som den koples direkte til den midtre delen av tynntarmen (5).

For at det skal være nevnt, utføres det fortsatt såkalt duodenal switch, men mye sjeldnere nå enn tidligere. Dette inngrepet er assosiert med betydelig malabsorpsjon, og det er stor fare for underernæring og mangeltilstander (4).

\section{Fedmekirurgi for fertile}

Metoden som er ansett for å være mest effektiv for vektnedgang hos personer med alvorlig fedme, er fedmekirurgi (3). Kirurgi er imidlertid anbefalt bare til de med sykelig fedme. Dette gjelder da de som har en BMI over 40, eller de med BMI på 35 eller høyere som har tilleggstilstander som hypertensjon, diabetes eller høyt kolesterol (5). I tillegg innvilges operasjonen også til kvinner med fedmerelatert infertilitet (2). 
Harris og Barger viser generelt til en signifikant økning i forekomsten av fedmekirurgi. Omtrent fire av fem som fikk utført denne typen kirurgi, var kvinner (5). I Norge har antallet fedmeopererte frem til 2013 ellevedoblet seg på ti år, og årlig gjennomgår rundt 3000 personer fedmekirurgi her til lands (23). Vekttap etter fedmekirurgi varierer med typen inngrep, men estimeres å være alt fra 14 til 80 prosent av overvekten (4).

\section{三 «Årlig gjennomgår rundt 3000 personer fedmekirurgi her til lands.»}

Den drastiske økningen i antallet fedmeoperasjoner vil føre til at flere kvinner som tidligere på grunn av overvekt og fedme var infertile, nå blir gravide. Vekttapet vil kunne føre til økt fertilitet $(4,5)$, og da spesielt for kvinner med polycystisk ovarialsyndrom, da de kan få tilbake normal eggløsning (4).

Disse kvinnene vil søke hjelp i svangerskapsomsorgen. Det er dermed viktig at jordmor har kunnskap om hvordan hun best kan ivareta akkurat denne gruppen kvinner og deres ufødte barn.

\section{Ernæringsstatus}

Velkjente komplikasjoner etter fedmekirurgi, og da spesielt etter malabsorptive prosedyrer, er ernæringsmangler og mangel på vitaminer og mineraler. Samtidig viser litteraturen at også anemi og forandringer i hemoglobinnivå forekommer etter slike operasjoner (3). Andre studier viser at de kvinnene som har gjennomgått kirurgi, også har økt risiko for anemi i svangerskapet (3). 
Mangelfull ernæringstilstand hos kvinnen kan igjen påvirke fosterets ernæringstilstand og videre fostervekst og utvikling (6). Studier som har tatt for seg ernæringsstatus hos pasienter som har gjennomgått gastrisk bypass-kirurgi, viser lave nivåer av sink, jern, magnesium, betakaroten, D-vitamin og vitamin B12 (5).

\section{三 «Mangelfull ernæringstilstand hos kvinnen kan påvirke fosterets ernæringstilstand $0 \mathrm{~g}$ videre fostervekst og utvikling.»}

Flere casestudier beskriver ernæringsmangler hos kvinner som blir gravide etter gjennomgått fedmekirurgi. Bebber og medarbeidere (7) fant at disse kvinnene ofte hadde lave nivåer av vitamin B12, folsyre, ferritin, albumin og kalsium. Absorpsjonen av vitaminer og mineraler blir minimalt påvirket av LAPband-prosedyren, og mangeltilstander er mindre sannsynlige hos disse kvinnene enn hos dem som har gjennomgått RYGB, hvor mesteparten av magesekken og duodenum er forbipassert (5).

Samtidig peker Dalfrà og medarbeidere (6) på at mangeltilstander også kan oppstå hos de kvinnene som har gjennomgått restriktive prosedyrer. Det er imidlertid på generell basis observert at overvektige pasienter ofte mangler D-vitamin og har jernmangelanemi. Da en del av disse kvinnene fortsatt er å regne som overvektige selv etter gjennomgått fedmekirurgi, trenger dette derfor ikke alltid ha sin årsak i gjennomgått kirurgi (5).

\section{Kaloriinnhold i morsmelk}


Det ble for en tid siden rapportert om fem tilfeller av alvorlig intrakraniell blødning hos nyfødte av mødre som hadde gjennomgått ulike typer fedmekirurgi. Dette kan sannsynligvis relateres til maternell Kvitaminmangel, og dermed også til K-vitaminmangel hos fosteret. Både Harris og Barger (5) og Dalfrà og medarbeidere (6) viser til disse funnene i sine studier.

Men selv om K-vitaminmangel er rapportert etter fedmekirurgi, er ikke det blant de mest hyppig forekommende mangeltilstandene (5). Antallet barn det vises til i disse studiene, er likevel for lite til å være representativt, og en skal derfor være forsiktig med å trekke konklusjoner om at K-vitaminmangel med sikkerhet kan knyttes til fedmekirurgien.

Det er post partum observert lave verdier av vitamin B12 i morsmelken til kvinner som har en historie med fedmekirurgi. Dette har sannsynligvis sammenheng med mors mangel på den faktoren som trengs for å absorbere B12 (2).

Dersom det også foreligger malabsorpsjon av fett, kan kaloriinnholdet i morsmelken være lavere, noe som igjen kan påvirke den nyfødtes vekst. Harris og Barger presiserer imidlertid i sin artikkel at det trengs mer forskning på området for å kunne si noe om disse barna er en risikogruppe (5).

\section{Komplikasjoner}

Det forekommer også kirurgiske komplikasjoner under svangerskap hos disse kvinnene. Komplikasjonsraten ligger opp mot 5 prosent, uavhengig av om det dreier seg om malabsorptive eller restriktive inngrep (5). 
Den mest vanlige og alvorligste komplikasjonen for kvinner som er gravide etter fedmekirurgi, er tarmhernier. Når uterus vokser under svangerskap og graviditet, vil den forskyve andre indre organer, og dermed føre til et økt abdominalt trykk. Dette trykket kan igjen føre til at deler av tarmen presses ut i «tomrom» etter tapt fett som følge av operasjonen, og dermed kan det oppstå avklemming og tarmobstruksjon (5).

Adherenser (sammenvoksinger) etter fedmekirurgi øker også risikoen for tarmhernier.

Det er tre perioder av graviditeten hvor det er økt risiko for tarmhernier: i midten av graviditeten, når uterus blir et abdominalt organ; ved termin, når fosterets hode går ned i bekkenet; og i post partumperioden, når uterus på kort tid skal tilbake til sin opprinnelige størrelse (5).

De kvinnene som har gjennomgått fedmekirurgi, og som har fătt komplikasjoner i form av tarmhernier, rapporterte om kvalme, oppkast og magesmerter. I de fleste tilfellene kom behandlingen sent, noe som resulterte i høy forekomst av neonatal og maternell dødelighet (8). Dette er alvorlig, og igjen understrekes viktigheten av at jordmor kjenner til komplikasjoner som kan oppstå hos gravide kvinner som har gjennomgått fedmekirurgi, slik at det kan fanges opp tidlig og en kan unngå tragiske utfall.

\section{Perinatale utfordringer}

Som tidligere nevnt er den største utfordringen i svangerskapet hos disse kvinnene ernærings- og mangeltilstander, noe som igjen kan påvirke fostertilveksten. Kvinner som har gjennomgått gastric banding-operasjoner, har liten kapasitet i magesekken, og kan ikke innta ubegrensede mengder mat og drikke på en gang. 
Under svangerskap øker væskebehovet, og disse kvinnene kan derfor være i risikosonen for å bli dehydrerte. Kvalme og oppkast i tidlig graviditet kan også komplisere svangerskapet (5).

Et relativt nytt funn er at kvinner som har gjennomgått kirurgi, oftere blir indusert enn sykelig overvektige. En fant også hyppigere forekomst av blodtransfusjon etter fødsel og venøse tromboembolismer hos denne gruppen kvinner (9). Kjær og medarbeidere finner imidlertid ikke belegg i sin studie for å si at risikoen for indusert fødsel er økt hos denne gruppen kvinner, sammenliknet med en kontrollgruppe (10).

\section{TROMBOEMBOLISME}

Blodpropp som løsner og følger blodstrømmen inntil dimensjonen på blodkaret ikke lenger tillater videre passasje, og proppen setter seg fast.

Kilde: Store medisinske leksikon

Det er gjort flere studier på neonatale utfall etter fedmekirurgi. Disse har spesielt tatt for seg prematur fødsel, lav fødselsvekt, makrosomi (stort foster) og perinatal dødelighet. Flere av studiene har imidlertid ikke vist at fedmekirurgi har noen skadelig effekt på nyfødte barn (5).

\section{PERINATALE TIDSBEGREP}

- Perinatalperiode: svangerskapstiden fra når fosteret antas å være levedyktig, til en uke etter fødselen

- Tidlig neonatalperiode: barnets første leveuke

- Neonatalperioden: barnets første levemåned

Kilde: Jordmorboka 
Studier av gastric banding viser lavere forekomst av makrosomi og lav fødselsvekt sammenliknet med gravide kvinner med fedme $(5,11)$. Dette støttes også av både Shai og medarbeidere (3) og Kjær og medarbeidere (10), hvor det kommer frem at kvinner som har gjennomgått fedmekirurgi, har mindre sannsynlighet for å føde store barn sammenliknet med sykelig overvektige gravide kvinner.

\section{Lavere fødselsvekt}

Dersom en sammenlikner graviditet hos kvinnene før og etter fedmekirurgi, er det også funnet signifikant lavere fødselsvekt etter gjennomgått operasjon (6). Det fremkommer av studien til Johansson og medarbeidere (11) at tendensen hos de fedmeopererte kvinnene er at de har lavere risiko for svangerskapsdiabetes og LGAbarn (barnet er stort i forhold til svangerskapsalder), og kortere gestasjonsalder (alderen på fosteret på et bestemt tidspunkt) enn kontrollgruppen.

Kjær og medarbeidere fant heller ingen signifikant forskjell når det gjaldt overføring av nyfødte barn av fedmeopererte mødre til intensivavdeling (10). På den andre siden finner Johansson og medarbeidere i sin studie at risikoen for dødfødsel eller neonatal død var høyere hos kvinnene som hadde gjennomgått fedmekirurgi, sammenliknet med kontrollgruppen (1,7 prosent versus 0,7 prosent) (11).

Samtidig må det bemerkes at 98 prosent av kvinnene fra studien til Johansson og medarbeidere (11) hadde gjennomgått gastrisk bypass-kirurgi, og en må derfor være forsiktig med å trekke konklusjoner for andre typer prosedyrer.

\section{Preterm fødsel}


Kohortstudien til Stephansson og medarbeidere viser

til funn som peker i retning av at gjennomgått

fedmekirurgi er assosiert med risiko for preterm

fødsel. Risikoen for moderat preterm fødsel mellom 32

og 36 fullgåtte svangerskapsuker var større blant

kvinner som hadde gjennomgått fedmekirurgi, sammenliknet med en kontrollgruppe av kvinner som ikke hadde gjort et slikt inngrep. De fant på den andre siden ingen signifikant forskjell mellom gruppene når det gjaldt preterm fødsel før 32 fullgåtte uker (12).

Til sammenlikning finner ikke Abenhaim og medarbeidere i sin studie belegg for å si at risikoen for preterm fødsel er større for denne gruppen kvinner (9). Det gjør heller ikke Johansson og medarbeidere (11). Dette kan imidlertid kanskje forklares ut fra kontrollgruppen i Abenhaim og medarbeideres studie, som besto av sykelig overvektige gravide kvinner.

Disse har som tidligere nevnt økt risiko for preterm fødsel (9).

\section{«Enkelte studier har avdekket en høyere risiko for å få barn som er små for alderen.»}

Når det gjelder risikoen for at disse mødrene får SGAbarn (barnet er lite i forhold til svangerskapsalder), er det en del sprik i litteraturen. Enkelte studier har avdekket en høyere risiko for å få barn som er små for alderen (13), og også en høyere forekomst av intrauterin veksthemning (14). Abenhaim og medarbeidere viser i sin ferske studie til funn som peker i retning av at intrauterin veksthemning faktisk forekommer hyppigere hos kvinner som har gjennomgått fedmekirurgi, sammenliknet med sykelig overvektige kvinner (9). 
Den registerbaserte kohortstudien til Kjær og medarbeidere konkluderer med at nyfødte av mødre som har gjennomgått fedmekirurgi, har lavere fødselsvekt, lavere gestasjonsalder og 2,3 ganger høyere risiko for å være SGA-barn sammenliknet med en matchende gruppe kvinner som ikke har gjennomgått fedmekirurgi. Forekomsten av SGA-barn var i tillegg høyere hos gruppen som hadde gjennomgått gastrisk bypass-kirurgi (10).

Disse funnene støttes av Johansson og medarbeidere, som også finner høyere risiko for SGA-barn hos de fedmeopererte kvinnene (15,6 prosent versus 7,6 prosent i kontrollgruppen) (11). Dalfrà og medarbeideres litteraturstudie finner imidlertid ikke holdepunkter for å si at forekomsten av SGA-barn er større blant denne gruppen kvinner sammenliknet med normalbefolkningen (6), og er derfor å betrakte som motstridende til andre forskningsfunn.

\section{Oppfølging}

De fleste studiene som ligger til grunn for denne artikkelen, peker på at økt overvåkning av fedmeopererte kvinner under svangerskap, fødsel og barseltid er nødvendig $(5,10,11)$, nettopp på grunn av at historikk med fedmekirurgi assosieres med en rekke komplikasjoner (11). Kjær og medarbeidere understreker i sin studie at obstetrisk oppmerksomhet bør rettes mot ernæringsmangler hos mor, og også mot fosterets vekst (10).

Det har imidlertid vært utfordrende å finne gode svar i litteraturen på hva som konkret anbefales når det gjelder oppfølging av disse kvinnene, og da spesielt oppfølging fra jordmor. En faktor som imidlertid er verdt å nevne, er at gravide kvinner som har gjennomgått fedmekirurgi, synes å være mer overvektige enn de kontrollgruppene som er brukt i de forskjellige studiene. 
Overvekt i seg selv er som nevnt innledningsvis en velkjent årsak til flere komplikasjoner, blant annet makrosomi (6). Som jordmødre kjenner vi til komplikasjonene knyttet til makrosomi: fødselstraume, skulderdystosi, høyere mortalitet og lavere Apgar-skår (5).

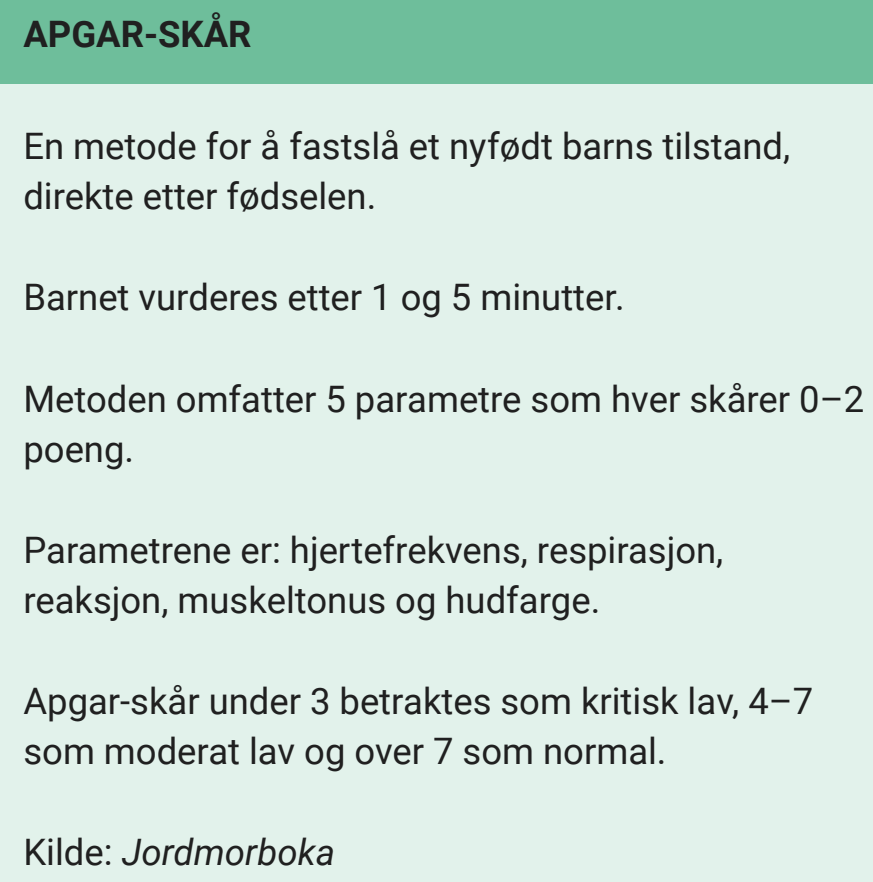

\section{Svangerskapet}

Det er viktig for jordmor å vite noe om på hvilket tidspunkt etter operasjonen kvinnen ble gravid, da det kan få konsekvenser for hvilken oppfølging kvinnen har behov for. Aleris overvektsklinikk anbefaler å vente i to år etter operasjon før en blir gravid, slik at en oppnår stabil vekt før svangerskap (15).

Grunnet potensielt stort vekttap, og derfor risiko for å utvikle vitamin- og mineralmangel, i tiden rett etter operasjonen og 12-18 måneder frem i tid anbefaler annen litteratur å vente med graviditet i minst 12-18 måneder etter operasjon $(4,5)$. Nymo og de Soysa hevder i sine anbefalinger at graviditet i en såkalt katabol fase øker risikoen for prematur fødsel, vekstretardasjon og næringsmangler hos barnet (4). 


\section{三 «Graviditet i en såkalt katabol fase øker risikoen for prematur fødsel, vekstretardasjon og næringsmangler.»}

På den andre siden hevder Harris og Barger at det ikke finnes belegg i litteraturen for å si at utfallet av graviditet og svangerskap forverres dersom kvinnen blir gravid før disse anbefalingene. Tvert imot har noen studier vist at det ikke er noen signifikante forskjeller i maternelle eller neonatale komplikasjoner som veksthemning, prematur fødsel eller hypertensjon (5).

Samtidig er det greit å være klar over at tidlig graviditet etter gjennomgått kirurgi kan føre til at det totale vekttapet etter operasjonen blir mindre, noe som kan medføre at kvinnen ikke oppnår optimal helseeffekt av inngrepet (4).

Videre vil en økt risiko for noen komplikasjoner henge sammen med på hvilket tidspunkt etter operasjonen kvinnen ble gravid. Mangel på folat før graviditet kan øke risikoen for nevralrørsdefekter hos fosteret (Hamre, 2010), og dersom kvinnen ble gravid på et tidlig tidspunkt etter operasjonen, kan det være grunn til å tro at et stort vekttap etter operasjon har medført vitamin- og mineralmangel. Dette vil imidlertid også være knyttet til hvilket inngrep kvinnen har gått gjennom, og kan ikke bare knyttes til tiden fra operasjon til svangerskap.

\section{Optimal vektøkning}

Nymo og de Soysa anbefaler tidlig kontroll hos jordmor eller fastlege. De anbefaler samtidig tidlig ultralyd ved 6-10 uker dersom det foreligger risikofaktorer som kan medføre misdannelser. Fostervekst bør monitoreres nøye. Symfyse-fundusmål (se illustrasjonsvideo under) fra uke 26, og deretter månedlig, anbefales (4). 
Metoden innebærer at avstanden mellom symfysen og toppen av livmoren måles med et målebånd.

Hensikten er å følge veksten av uterus og dermed få et grovt mål på fosterveksten.

Kilde: Jordmorboka

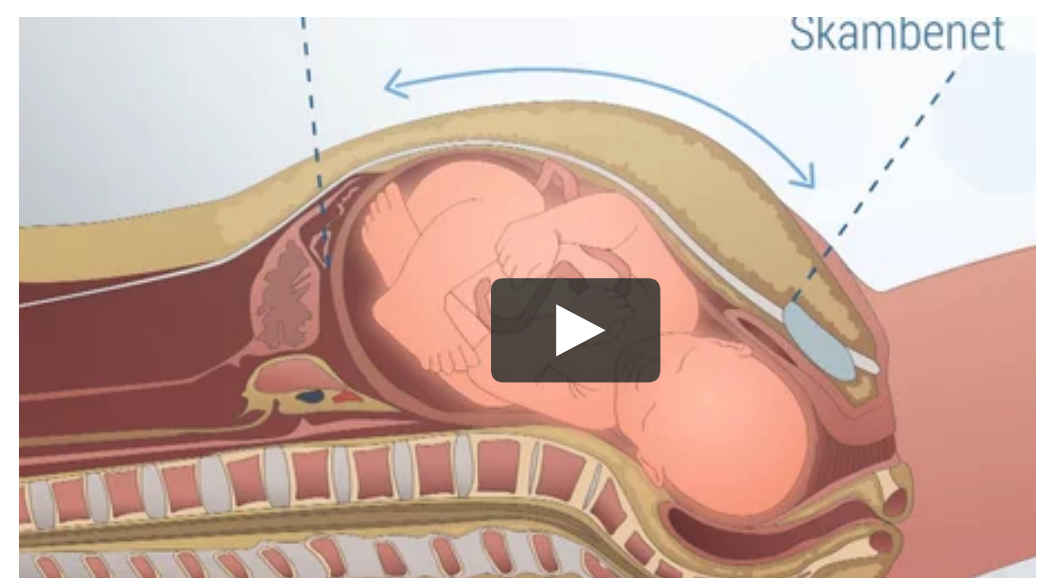

SYMFYSE-FUNDUS-MÅL. Videoen ble laget i forbindelse med symfyse-fundus-prosjektet, igangsatt av professor Bjørn Backe og overlege Hildegunn Stoum i samarbeid med NTNU Technology Transfer. Laget av Headspin Productions.

Ved første kontroll bør det i tillegg til standardblodprøver tas prøver som gir informasjon om kvinnens ernæringstilstand. Videre anbefales det at en tar slike prøver hver tredje måned i svangerskapet, og vekt bør måles ved alle kontroller. Stabil vekt utelukker imidlertid ikke malabsorpsjon av næringsstoffer, og fosteret har derfor økt risiko for ulike mangeltilstander (4).

Forskningen har så langt ikke gitt noe entydig svar på hva som er optimal vektøkning hos fedmeopererte gravide, men den gravides førgravide BMI danner utgangspunktet her. Mengde kosttilskudd bør vurderes hos disse kvinnene, men type og dosering avhenger av hvilken type kirurgi som er gjennomgått (4). 
Dersom en kvinne som er fedmeoperert, blir gravid under 24 måneder etter inngrepet, bør hun henvises til klinisk ernæringsfysiolog. Samtidig bør det vurderes om kvinnen har nytte av å bli henvist til ernæringsfysiolog også etter at det har gått 24 måneder etter gjennomgått fedmekirurgi. Ernæringsfysiologen vil kunne hjelpe jordmor dersom det kommer opp spørsmål rundt vekttap, manglende vektoppgang, stor vektoppgang, ved mistanke om eller påviste ernæringsmessige mangler og ved spørsmål om kosttilskudd, næringspreparater, sondeernæring eller intravenøs ernæring (4).

Gjennom egne erfaringer i praksisfeltet, og i samtale med gynekolog, kom det frem at ikke sjelden legges noen av disse kvinnene inn på observasjonsavdelingen for gravide, da de har behov for sondeernæring eller intravenøs ernæring. Viktigheten av tverrfaglig samarbeid i møte med disse kvinnene presiseres fra flere hold, det være seg jordmor, fastlege, gynekolog, ernæringsfysiolog, anestesilege og pediater $(5,6,17)$.

\section{Svangerskapsdiabetes}

Fedmeopererte gravide bør screenes for svangerskapsdiabetes. For jordmor er det viktig å vite at den vanlige glukosetoleransetesten (også kalt sukkerbelastningstest) ikke skal brukes til kvinner som er fedmeoperert $(4,5)$. Grunnen er at hurtig og stor tilførsel av sukker til en liten ventrikkel (magesekk) kan medføre det en kaller dumping. Dette kan medføre rask forflytning av glukose til tarmen, noe som igjen kan føre til blodtrykksfall, svimmelhet og diare (4).

Det anbefales derfor heller å måle fastende glukose og glukose etter frokost hver dag i en uke. Gravide kvinner som har gjennomgått kirurgi, kan altså trenge en annen tilnærming når det gjelder å avdekke en eventuell svangerskapsdiabetes, og derfor er det viktig at jordmor har kunnskap om dette. 


\section{三 «Hurtig og stor tilførsel av sukker til en liten ventrikkel (magesekk) kan medføre det en kaller dumping.»}

Hos kvinner som har gjennomgått laparoskopisk gastrisk banding, kan båndets diameter justeres noninvasivt. Dette kan være fordelaktig når kvinnen går gjennom et svangerskap. En slik justering kan føre til optimal ernæringsstatus for kvinnen, og dermed også jevn fostertilvekst (6). Kvalme og oppkast kan også reduseres ved at båndet justeres (5).

Noen gastrokirurger og obstetrikere slipper luften helt ut av båndet i svangerskapsuke 36 for å minimere risikoen for herniering, men også for å tilrettelegge for optimale ernæringsforhold knyttet til laktasjon og amming post partum (5). Kvinnen drar altså fordel av dette på flere måter: kontrollert matinntak gjennom graviditet og redusert risiko for mangeltilstander som ellers er assosiert med LAGB (6).

Forskningen peker imidlertid på at det ikke finnes noen praktiske retningslinjer for justering av båndet $\mathrm{i}$ svangerskap hos de kvinnene som har gjennomgått LAGB-prosedyren (5). Det må samtidig presiseres at denne typen inngrep ikke er så mye brukt i Norge (4), men det er likevel viktig for jordmødre å kjenne til at denne typen inngrep utføres i andre deler av verden.

Kvinner som på grunn av det kirurgiske inngrepet er i risikosonen for å bli dehydrert, bør oppfordres til alltid å ha med seg en flaske med vann og regelmessig drikke små mengder for å sikre tilstrekkelig væskeinntak (5). Væskeinntaket kan de første årene etter operasjon være lavt, og enkelte gravide kan trenge intravenøs tilførsel av væske for å sikre at inntaket blir tilstrekkelig (4).

\section{Konsultere gastrokirurg}


Jordmødre i svangerskapsomsorgen bør vie økt oppmerksomhet til gastrointestinale symptomer hos denne gruppen av kvinner (4). Gravide kvinner som har gjennomgått fedmekirurgi, skal tas på alvor dersom de under svangerskapet har symptomer som magesmerter og livmorkramper. Det samme gjelder ved kvalme, oppkast og brystsmerter.

Her kan tarmobstruksjon, hernier, perforasjon og blødning være differensialdiagnoser til andre graviditetsrelaterte diagnoser. Smerter knyttet til obstruksjon og hernier er som oftest intermitterende og oppstår mer sannsynlig etter matinntak.

Det kan være verdifullt å konsultere med en gastrokirurg under utredning av slike plager $\mathrm{i}$ svangerskapet. Generelt anbefales det at terskelen for å kontakte kirurg skal være lav dersom en mistenker komplikasjoner knyttet til gjennomgått fedmekirurgi (4).

\section{Fødselen}

Operasjonen i seg selv øker ikke behovet for ekstra oppfølging og pleie akkurat under fødselen. Samtidig kan som tidligere nevnt kirurgiske komplikasjoner oppstå, og det er økt risiko når fosterhodet trenger ned i bekkenet. Jordmor må derfor være på vakt dersom kvinnen klager på sterke magesmerter under eller rett etter fødselen (5).

Det som kan oppleves som utfordrende her, er at det kan være vanskelig å skille mellom det som er smerter knyttet til kirurgien, og fysiologiske fødselssmerter, da disse også for mange oppleves som veldig sterke (18). I Veileder i fødselshjelp (2014) fremkommer det at gjennomgått fedmeoperasjon i seg selv ikke er en indikasjon for keisersnitt (19).

\section{Barseltiden}


De fleste kvinner som har født vaginalt, opplever en viss grad av smerter i perineum (20). Etterrier kan også være smertefulle, spesielt for flergangsfødende (21). Førstevalget for jordmødre når det gjelder medikamentell smertelindring per os, er preparater som inneholder paracetamol.

Dersom dette ikke har ønsket effekt, bør kvinnen tilbys antiflogistika, for eksempel naproxen (NSAIDs) (20). Kvinner som har gjennomgått fedmekirurgi, skal imidlertid ikke ta NSAIDs for smerter i post partumperioden, da disse medikamentene kan skape sårdannelser (ulcerasjon) i den lille magesekken (5). Dette er det derfor viktig for jordmor å vite om.

Det er essensielt i barseltiden at jordmor fortsetter å overvåke ernæringsstatus hos disse kvinnene og deres nyfødte barn. Mangeltilstandene som følge av fedmekirurgi kan påvirke ammingen (2, 6). Det kan som tidligere nevnt oppstå vitamin B12-mangel hos barnet, eller kaloriinnholdet i morsmelken kan være lavt, noe som vil ha konsekvenser for barnets vekst.

\section{三 «Det er essensielt at jordmor fortsetter å overvåke ernæringsstatus hos disse kvinnene og deres nyfødte barn.»}

Pediatere skal umiddelbart informeres dersom en kvinne har gjennomgått slik kirurgi, og det er naturlig at dette blir jordmors oppgave. Videre kan pediateren gjøre vurderinger knyttet til behov for enterale eller parenterale vitamintilskudd hos disse mødrene og barn som ernæres med morsmelk (2, 5, 6). Med tilstrekkelig inntak av vitaminer og mineraler i laktasjonsperioden, og da spesielt kalsium, jern, folat, vitamin B12 og Dvitamin, kan kvinnen etter fedmekirurgi også oppleve vellykket amming (2). Barnets vekst i nyfødtperioden bør også monitoreres nøye (2). 
I Veileder i fødselshjelp oppgis det at effekten av ppiller kan reduseres på grunn av redusert absorpsjon etter fedmekirurgi (19). Dette må jordmor være klar over i en eventuell prevensjonsveiledning etter fødsel.

\section{Jordmors tilnærming}

Det er grunn til å tro at fedmeopererte kvinner, som tidligere har vært sykelig overvektige, har hatt negative erfaringer med kropp, vekt og kost. Det er da vesentlig med tydelighet og klare avtaler fra jordmors side i møte med disse kvinnene. Trygge rammer er en del av en helhetlig ivaretakelse av kvinnen og hennes barn (22).

Det er i enkelte deler av landet etablert poliklinikker for overvektige gravide, der kvinnene får tett oppfølging med kostholdsveiledning og råd om fysisk aktivitet. Samtidig blir den psykiske helsen ivaretatt. Ernæringsfysiolog er ofte en ressurs (22), jamfør det som tidligere er skrevet om tverrfaglig samarbeid.

Videre kan det nevnes at tidligere historikk med fedme kan gjøre kvinnene mer utsatt for post partumdepresjon (5). Jordmor må derfor være ekstra på vakt overfor disse kvinnene. Kroppen er igjen endret etter fødsel, og det er viktig å ha en åpen dialog om følelsene kvinnene har rundt kroppslige endringer etter gjennomgått svangerskap og fødsel (Laache, 2010).

\section{Konklusjon}

Den økende forekomsten av fedme i befolkningen medfører også at flere kvinner søker hjelp i helsevesenet og får gjennomført fedmekirurgi som behandling mot overvekt og fedme. Kvinner i fertil alder utgjør en stor del av denne gruppen, og det er trolig at dette er en gruppe kvinner som jordmødre i økende grad vil møte i forbindelse med svangerskap, fødsel og barseltid. 
Det er tydelig at jordmødre har behov for økt kunnskap om dette saksfeltet, nettopp for å kunne fange opp de tilfellene som krever ekstra oppfølging. Jordmor skal jobbe kunnskapsbasert, og det er derfor avgjørende å vite noe om dette temaet for å gi kvinnene best mulig oppfølging.

Fedmekirurgi tillater kvinnene å ha sunnere helse, lavere risiko i svangerskap og avkom med lavere risiko for å utvikle overvekt og overvekstrelaterte tilstander senere i livet - alt dette som følge av mors fedmeoperasjon. Sikkerheten rundt svangerskap der kvinnen har gjennomgått fedmekirurgi, har vært kartlagt i flere studier de siste årene.

Foreløpig har det ikke blitt påvist at fedmekirurgi kan relateres til dårligere utfall som perinatale dødsfall og kongenitale (medfødte) malformasjoner (misdannelser)

(3). Forskningen viser heller at kvinner som har gjennomgått fedmekirurgi, har bedre utfall av graviditet sammenliknet med gravide kvinner med sykelig overvekt eller fedme (9).

\section{三 «Kvinner som har gjennomgått fedmekirurgi, har bedre utfall av graviditet sammenliknet med gravide kvinner med sykelig overvekt eller fedme.»}

Det er høyst sannsynlig at den potensielle risikoen for den gravide kvinnens og fosterets under- og feilernæring kan balanseres med nøye oppfølging av mødrene i svangerskapet og bruk av næringstilskudd (6). 
Det kan synes selvsagt at mangeltilstander etter fedmekirurgi er til å unngå, og enklere å behandle enn fedme i seg selv (3). Samtidig er det ikke dermed sagt at det ikke er utfordringer som følger med disse kvinnene når de gjennomgår svangerskap, fødsel og barseltid. Kirurgiske komplikasjoner kan oppstå, og jordmor må være bevisst dette i oppfølgingen av kvinnen.

\section{Referanser}

1. Kaska L, Kobiela J, Abacjew-Chmylko L, Wojanovska-Pindel PK, Walerzak A, Makarewicz W, et al. Nutrition and pregnancy after bariatric surgery. ISRN Obese. 2013. 492060.

2. Jevitt C. Pregnancy complicated by obesity: midwifery management. Journal of Midwifery \& Women's Health. 2009;54(6):445-51.

3. Shai D, Shoham-Vardi I, Amsalem D, Silverberg D, Levi I, Sheiner E. Pregnancy outcome of patients following bariatric surgery as compared with obese women: a population-based study. The Journal of Maternal-Fetal \& Neonatal Medicine. 2014;27(3):275-8.

4. Nymo S, de Soysa AKH. Veileder for leger, jordmødre og kliniske ernæringsfysiologer i ernæringsoppfølging ved høyrisikosvangerskap: den gravide fedmeopererte. Referansegruppen for fedmekirurgi. Trondheim: Kliniske ernæringsfysiologers forening tilsluttet Forskerforbundet; 2014.

5. Harris AA, Barger MK. Specialized care for women after bariatric surgery. Journal of Midwifery \& Women's Health. 2010;55:529-39.

6. Dalfrà MG, Busetto L, Chilelli NC, Lapolla A. Pregnancy and foetal outcome after bariatric surgery: a review of recent studies. The Journal of Maternal-Fetal \& Neonatal Medicine. 2010;25(9):1537-43. 
7. Bebber FE, Rizolli J, Casagrande DS, Rodriques MT, Padoin AV, Mottin CC, et al.

Pregnancy after bariatric surgery: 39 pregnancies follow-up in a multidisciplinary team. Obes Surg. 2011;21(10):1546-51.

8. Guelinckx I, Devlieger R, Vansant G.

Reproductive outcome after bariatric surgery: a critical review. Human reproduction update. 2009 marsapril;15(2):189-201.

9. Abenhaim HA, Alrowaily N, Czuzoj-Shulman $\mathrm{N}$, Spence AR, Klam SL. Pregnancy outcomes in women with bariatric surgery as compared with morbidly obese women. The Journal of Maternal-Fetal \& Neonatal Medicine. 2016;29(22):3596-601.

10. Kjær MM, Lauenborg J, Breum BM. The risk of adverse pregnancy outcome after bariatric surgery: a nationwide register-based matched cohort study. American Journal of Obstetrics and Gynecology. 2013;208(6):464.e1-5.

11. Johansson K, Cnattingius S, Näslund I, Roos N, Lagerros YT, Granath F, et al. Outcomes of pregnancy after bariatric surgery. The New England Journal of Medicine. 2015;372:814-24.

12. Stephansson O, Johansson K, Näslund I, Neovius M. Bariatric surgery and preterm birth. New England journal of medicine. 2016;375:805-6.

13. Marceau P, Kaufman D, Biron S. Outcome of pregnancies after biliopancreatic diversion. Journal of Obesity Surgery. 2004;14(3):318-24.

\section{Sheiner E, Edri A, Balaban E, Levi I, Aricha-} Tamir B. Pregnancy outcome of patients who conceive after the first year following bariatric surgery. American Journal of Obstetrics and Gynecology. 2011;204(1):50.e1-6. 
15 Aleris Overvektsklinikk. Gravid etter

slankeoperasjon. Oslo; 2016. Tilgjengelig fra:

http://overvekt.net/etter-operasjon/gravid-etter-

slankeoperasjon/ (nedlastet 21.11.2016).

16. Hamre B. Svangerskapsomsorg. I: Brunstad A, Tegnander E, red. Jordmorboka. Oslo: Akribe; 2010.

17. Skogøy K, Laurini R, Aasheim ET.

Svangerskap like etter fedmeoperasjon. Tidsskrift for

Den norske legeforening. 2009;129:534-6.

Tilgjengelig fra:

http://tidsskriftet.no/sites/tidsskriftet.no/files/pdf2009

-534-6.pdf (nedlastet 09.01.2017).

18. Ulvund I. Fødselssmerte og smertelindring. I: Brunstad A, Tegnander E, red. Jordmorboka. Oslo: Akribe; 2010.

19. Henriksen T, Overrein H, Kardell K, Skogøy K. Adipositas og svangerskap og fødsel. I: Veileder i fødselshjelp. Oslo: Norsk gynekologisk forening; 2014. Kapittel 15.

20. Reinar LM. Plager og komplikasjoner. I: Brunstad A, Tegnander E, red. Jordmorboka. Oslo: Akribe; 2010.

21. Venheim MA. Barselomsorg. I: Brunstad A, Tegnander E, red. Jordmorboka. Oslo: Akribe; 2010.

22. Laache I. Tilstander hos kvinnen som kan påvirke svangerskap, fødsel og barseltid. I: Brunstad A, Tegnander E, red. Jordmorboka. Oslo: Akribe; 2010.

23. Leknes, BO. Fedmeoperasjoner - ingen lettvint løsning. forskning.no. 2013. Tilgjengelig fra: https://forskning.no/mat-menneskekroppenovervekt/2013/02/fedmeoperasjoner-ingen-lettvintlosning (nedlastet 22.03.2018). 